\title{
ENVIRONMENTALLY RELATED OXIDATIVE STRESS (EROS) IN CHILDREN CARCINOGENESIS: AN OVERVIEW AND OWN DATA
}

\author{
S. K. Pinaev* \\ Far Eastern State Medical University, Khabarovsk, Russia
}

\begin{abstract}
According to the report of the International Agency for Research on Cancer, more than 100 different factors of chemical and physical nature are recognized as carcinogenic. Many ecological factors provide their potential through environmentally related oxidative stress (EROS) induction, which can be considered as an "assemblage point" of various environmental factors into a single oncogenic vector. Based on the role of EROS in oncogenesis, measures for the prevention of all forms of malignant neoplasms have to include means that improve antioxidant protection by stimulating autophagy and Transfer Factor for an effective immunorehabilitation.
\end{abstract}

Keywords: Solar radiation, ecology, environmental factors, oxidative stress, smoke, forest fires, prenatal, postnatal, children, carcinogenesis, neoplasms, childhood cancer

Every year the study of the molecular mechanisms of carcinogenesis highlights more and more details of this process. Some of them serve as a springboard for a new round of research, while others form the basis for new targeted medications for tumor therapy. A positive consequence of this is an increase in the degree of personalization and targeting of the treatment process, but, unfortunately, often without obvious increase in the final efficiency. Therefore, it is still important to study the universal mechanisms of oncogenesis that can serve as the basis for implementing new systemic approaches to the prevention and treatment of cancer. One of such universal mechanisms is environmentally related oxidative stress (EROS).

Currently, the role of the external environment in the neoplasms development is generally recognized. According to the report of the International Agency for Research on Cancer (IARC), more than 100 different factors of chemical and physical nature are recognized as carcinogenic [1].

It is difficult to overestimate the electromagnetic pollution of the environment that has been growing every year. The International Agency for Research on Cancer (IARC) has classified radio-frequency electromagnetic radiation, including mobile communications, as a possible human carcinogen [2] and according to the data the experts published in 2019, the hazard class is be increased [3].

Environmental factors play a special role in oncogenesis in young children of $0-4$ years old. A peculiarity of tumor pathology of this period is its prenatal genesis, a close connection between the processes of embryogenesis and organogenesis with carcinogenesis, as well as a relatively short time between the effect of environmental factors and the development of neoplasias. In this regard, malignant neoplasms in young children can be considered as a sensitive indicator of the carcinogenic effect of environmental factors on the human population.

At present, it has been found out that many childhood malignancies are associated with certain environmental factors. Thus, exposure to solvents and pesticides has been shown to be positively associated with the risk of childhood leukemia [4]. Contact of the expectant mother with gasoline and diesel fuel significantly increases the chances of retinoblastoma in children $[5,6]$.

About 5-10\% of malignant neoplasms in children are associated with ionizing radiation [7]. Prenatal and neonatal ionizing radiation, according to some authors, increases the risk of leukemia $[7,8]$, while others mention harmful influence of radiation exposure during pregnancy, but deny the role of postnatal exposure [9].

Solar activity, according to our data, has a direct reliable dependence on the incidence of leukemia and non-Hodgkin's lymphomas in children $[10,11]$, that may be due to changes in the Earth's magnetic field under the influence of the Sun.

Ultraviolet radiation from the Sun, according to the literature, increases the risk of retinoblastoma [12] and embryonic tumors of the central nervous system, but reduces the risk of developing hepatoblastoma [13], acute lymphoblastic leukemia and non-Hodgkin's lymphoma in children $[13,14]$, presumably due to the stimulation of vitamin D production [14].

Smoke is an important environmental factor with proven mutagenic and genotoxic effects [15]. It has been revealed that smoking of parents before and during pregnancy can be a risk factor for the development of lymphomas and tumors of the central nervous system (CNS) in a child [16]; prenatal exposure to wood-fired smoke also increases the risk of 
developing CNS tumors in children [17]. Numerous studies indicate that there is a connection between childhood leukemia and the effects of tobacco smoke and exhaust gases on expectant parents before conception, and then during pregnancy and in the first years of children's life $[4,8,16,18,19,20,21]$.

Maternal smoking before and during pregnancy, as well as exposure to gasoline and diesel combustion products, significantly increases the chances of retinoblastoma in children [5,6], similarly, parental smoking increases the risk of developing hepatoblastoma in childhood [22].

According to our data, there is a strong connection between the number of forest fires and the incidence of CNS tumors, as well as Hodgkin's lymphoma, leukemia, and embryonic tumors in the population of young children [10,11,23,24].

Many environmental factors provide their oncogenic potential through oxidative stress induction. Bisphenol A, active and passive smoking $[25,26]$ lead to the development of oxidative stress. The amount of carbon microparticles PM2.5 and PM10 in smoke due to the use of biomass as a fuel in cooking correlates positively with the depletion of antioxidant enzymes and increased lipid peroxidation [27,28]. An alternating magnetic field of $50 \mathrm{~Hz}$ and static magnetic fields, cause an increase in the activity, concentration and lifetime of paramagnetic free radicals with the development of oxidative stress [29,30]. That is precisely why oxidative stress should be considered as an "assemblage point" of various environmental factors into a single oncogenic vector.

EROS determined also in addition to the oxidative stress itself due to an imbalance in the system of "reactive oxygen species (ROS) - antioxidants" by nitrosative and carbonyl stress, characterized by excessive formation of reactive nitrogen and carbon species respectively, and reductive stress that occurs when the levels of free radicals are reduced [31,32].

The result of the impact of EROS is largely determined by the period of ontogenesis when this impact occurs [31,32]. Thus, the participation of environmental factors in oncogenesis in children through EROS can be represented as follows. After their onset oxidative stress launches a chain reaction of the formation of secondary radicals, as well as due to the growing bias in the oxidant-antioxidant system due to the depletion of the level of antioxidant enzymes $[27,28]$ and dysfunction due to the formation of crosslinks between the polypeptide chains of protein molecules [31,32].

The state of mitochondria plays a key role in the development and maintenance of the oxidantantioxidant imbalance, since their dysfunction can be one of the reasons for increased sensitivity to the effects of environmental factors, and after the onset of oxidative stress, it can become its consequence, thus closing the pathological circle [33,34].

Acetylation of histones plays an essential role in oncogenesis. It has been shown that double and triple methylated histones are associated with the development of various hematological cancers [35]. According to the IARC monograph "Air pollution and cancer" in experimental studies in vitro and in vivo 86 altered DNA methylation, histone modification, and other classes of epigenetic modifications were observed after exposure to tobacco smoke, carbon black, diesel exhaust, wood smoke, bisphenol A, chromium, nickel, arsenic, and cadmium [14]. Exposure to both static magnetic fields and an alternating magnetic field of 50 $\mathrm{Hz}$ can increase the activity, concentration and lifetime of paramagnetic free radicals, and lead to genetic mutations [29,30].

The growing EROS leads to epigenomic modulation of the functioning of genes involved in oncogenesis and tumor development. It was found out that aldehydes arising as a result of carbonyl stress can simultaneously form bonds with proteins and nitrogenous bases of DNA by forming cross-links between polypeptide and polynucleotide chains, resulting in chromosomal aberrations and inhibition of gene expression [31,32].

The increased metabolic activity of cancer cells causes high concentrations of ROS, which leads to a number of events that contribute to the development of tumors, such as DNA damage, genome instability, oncogene activation, sustained proliferation, and survival. Elevated ROS concentrations also cause protective growth of cancer cells with an increased antioxidant capacity to support tumor-stimulating signaling. An increase in the ROS level to the toxicity threshold, for example, by treatment with exogenous ROS inducers or antioxidant inhibitors, causes oxidative damage to cells and, inevitably, cell death.

The process of tumor transformation can be also directly triggered by MICAL proteins. The MICAL family is represented by redox-active enzymes that mediate semaphorin signaling and are direct regulators of cell shape and motility. MICAL proteins work through specific, reversible post-translational actin oxidation, providing disassembly and reconstruction of the cytoskeleton, that supports many aspects of the behavior of both normal and cancer cells [36].

EROS has a direct immunosuppressive effect, as the cells of the immune system are especially vulnerable due to their high metabolic activity and their own production of ROS [33]. The resulting immunodeficiency, in its turn, increases the chances of survival in transformed cells.

Since the studies of the last 20 years have revealed significant contradictions between the study of the antioxidant properties of medications in vitro and their action in the body [37], at present, special attention is paid to the study of endogenous mechanisms of antioxidant defense [32,38].

Autophagy is an effective way to protect against the development of EROS and to stop its consequences [38]. Antioxidant-inducing effects of Chinese herbal medicine (quercetin, epigallocatechin gallate, resveratrol, constituents of Portulaca oleracea L., Forsythia sussa, Andrographis paniculata, Astragalus membranaceus) show the reducing inflammatory mediators, inhibiting tumor proliferation and angiogenesis, suppressing metastasis, overcoming drug resistance and decreasing the side effects of chemo and radiotherapy by inhibiting glycolysis, regulation of ROS-related transcription factors (NRF2, NF- $\kappa \mathrm{B}, \mathrm{COX}-$ 2, STAT3, HIF-1a) and by enhancing the capacity of 
antioxidant enzymes such as GSH, SOD, and HO-1 [39].

The prooxidant effects of Chinese herbal medicine in cancer cells are achieved by increasing the production of ROS and / or by inhibiting the antioxidant capacity, thereby activating ROSdependent models of cancer cell killing. Apoptosis induces a signaling pathway with activation of apoptotic executive molecules, autophagic cell death, necroptosis, and ferroptosis [39].

The ability to activate NRF2 has been detected in curcumin and a group of compounds related to alkyl catechols. Alkyl catechols used in fermented food and beverages are formed there by Lactobacillus plantarum, Lactobacillus brevis and Lactobacillus collinoides, synthesizing them from phenolic acids found in fruit and vegetables [40,41].

\section{CONCLUSION}

Currently, taking into account the accumulated knowledge about the causes of leukemia in children, some authors say that this is the disease that can and must be prevented $[4,21]$. This is quite applicable to other malignant neoplasms in children, if we approach them from the standpoint of environmental conditioning, and the involvement of oxidative stress in their pathogenesis.

How can the effects of exposure to adverse environmental factors be reduced? To be protected against harmful effects of smoke, expectant parents may be advised to avoid staying in smoky places 1 year prior planned conception. To protect the respiratory organs they should use effective respirators and purify the indoor air with filters. Similar recommendations may be applied for the protection of newborns and young children.

The method of protecting future children from increased solar activity might be, if possible, planning pregnancy during periods of the quieter Sun. However, it seems that such recommendations are very difficult to implement.

Therefore, based on the systemic mechanism of the oncogenic effects of environmental factors, and the role of EROS in oncogenesis, measures for the prevention of all forms of malignant neoplasms in children have to include means that improve antioxidant protection.

Measures of malignant neoplasms prevention in young children, among other things, have to be aimed at improving antioxidant protection in future parents, young mothers, as well as young children themselves [21]. It is recommended to consume a sufficient amount of vitamins, including folates, and regularly include fresh vegetables, fruit [4,21] and food that improve autophagy processes in a diet [40,41].

Excessive hygiene while caring for children, with much attention to maintaining sterile cleanliness, is a risk factor for the development of malignant neoplasms, since the lack of microbial exposure at an early stage of life leads to impaired functioning of the immune system. Therefore, the best prevention of cancer is the cohabitation and communication of children of different ages, and long-term breastfeeding $[4,21]$.

Moreover, taking into account the immunosuppressive effect of EROS, it is seems appropriate add to the protective complex Transfer Factor for an effective immunorehabilitation. It is included in the Prescriber's Digital Reference and recommended by the Russian Ministry of Health $[42,43]$.

Thus, in our opinion, the investigation of the role of EROS in oncogenesis and further study of the molecular mechanisms of this process can be considered a promising direction that will help to find new approaches and solutions in the fight against cancer.

Acknowledgements: The author would like to thank to Alexey Yaroslavovich Chizhov for valuable creative discussion, and to Nikolai Eduardovich Kosykh for help in collecting materials.

\section{REFERENCES}

1. V. J. Cogliano, R. Baan, Straif K., Y. Grosse, B. Lauby-Secretan et al., "Preventable exposures associated with human cancers", J. Natl. Cancer Inst., vol. 103, no. 24, pp. 1827-1839, 2011. https://www.doi.org/10.1093/jnci/djr483

2. IARC monographs on the identification of carcinogenic hazard to humans, "Agents Classified by the IARC Monographs", vol. 1-127. Retrieved from:

https://monographs.iarc.fr/list-of-classifications

3. A. B. Miller, M. E. Sears, L. L. Morgan, D. L. Davis, L. Hardell et al., "Risks to Health and Well-Being From Radio-Frequency Radiation Emitted by Cell Phones and Other Wireless Devices", Front. Public Health, vol. 7, art. 223, 2019.

https://www.doi.org/10.3389/fpubh.2019.00223

4. S. Azary, A. Ganguly, G. R. Bunin, C. Lombardi, A. S. Park et al., "Sporadic Retinoblastoma and Parental Smoking and Alcohol Consumption before and after Conception: A Report from the Children's Oncology Group", PLoS One, vol. 11, no. 3, e01517281-16, 2016.

https://www.doi.org/10.1371/iournal.pone.0151728

5. J. E. Heck, A. S. Park, J. Qiu, M. Cockburn, B. Ritz, "Retinoblastoma and ambient exposure to air toxics in the perinatal period", J. Expo. Sci. Environ. Epidemiol., vol. 25, no. 2, pp. 182-186, 2015.

https://www.doi.org/10.1038/jes.2013.84

6. C. Modonesi, E. Oddone, C. Panizza, G. Gatta, "Childhood cancer and environmental integrity: a commentary and a proposal”, Rev. Saude Publica., vol. 51, 2017.

https://www.doi.org/10.1590/S15188787.2017051006744

7. A. Cárceles-Álvarez, J. A. Ortega-García, F. A. LópezHernández, M. Orozco-Llamas, B. Espinosa-López et al., "Spatial clustering of childhood leukaemia with the integration of the Paediatric Environmental History", Environ. Res., vol. 156, pp. 605-612, 2017. https://www.doi.org/10.1016/j.envres.2017.04.019

8. R. J. McNally, L. Parker, "Environmental factors and childhood acute leukemias and lymphomas", Leuk. Lymphoma., vol. 47, no. 4, pp. 583-598, 2006. https://www.doi.org/10.1080/10428190500420973

9. S. K. Pinaev, O. G. Pinaeva, A. Ya. Chizhov, "About the role of environmental factors in carcinogenesis", 
S. K. Pinaev, Environmentally related oxidative stress (EROS)..., RAD Conf. Proc., vol. 4, 2020, 85-89

Actual Problems of Ecology and Environmental Management: Cooperation for Sustainable Development and Environmental Safety (APEEM 202O), E3S Web of Conferences 169, 04003 (2020). https://doi.org/10.1051/e3sconf/202016904003

10. А. Я. Чижов, С. К. Пинаев, “Системный анализ влияния солнечной радиации и дыма лесных пожаров на риск лейкоза у детей”, Радиация и риск, том 27, no. 4, pp. 87-94. (A. Ya. Chizhov, S. K. Pinaev, "Effects of solar radiation and woodsmoke on risk of childhood leukaemia: system analysis", Radiation and Risk, vol. 27, no. 4, pp.87-94, 2018).

https://www.doi.org/10.21870/0131-3878-2018-274-87-94

11. M. L. Hooper, "Is sunlight an aetiological agent in the genesis of retinoblastoma?", Br. J. Cancer. vol. 79, no. 7-8, pp. 1273-12766, 1999.

https://www.doi.org/10.1038/sj.bjc.6690204

12. C. Lombardi, J. E. Heck, M. Cockburn, B. Ritz, "Solar UV radiation and cancer in young children", Cancer Epidemiol. Biomarkers Prev., vol. 22, no. 6, pp. 1118-1128, 2013.

https://www.doi.org/10.1158/1055-9965.EPI-121316

13. A. M. Hughes, B. K. Armstrong, C. M. Vajdic, J. Turner, A. E. Grulich et al., "Sun exposure may protect against non-Hodgkin lymphoma: a casecontrol study", Int. J. Cancer, vol. 12, no. 5, pp. 865-871, 2004.

https://www.doi.org/10.1002/ijc.20470

14. IARC Scientific Publications, 161, "Air pollution and cancer", Edited by K. Straif, F. Cohen, J. Samet, P.170, 2013.

Retrieved from:

http://publications.iarc.fr/Book-And-ReportSeries/Iarc-Scientific-Publications/Air-PollutionAnd-Cancer-2013

15. A. J. Sasco, H. Vainio, "From in utero and childhood exposure to parental smoking to childhood cancer: a possible link and the need for action", Hum. Exp. Toxicol., vol. 18, no. 4, pp. 192-201, 1999. https://www.doi.org/10.1191/096032799678839905

16. K. R. Greenop, A. L. Hinwood, L. Fritschi, R. J. Scott, J. Attia et al., "Vehicle refuelling, use of domestic wood heaters and the risk of childhood brain tumours: Results from an Australian case-control study", Pediatr. Blood Cancer, vol. 62, no. 2, pp. 229-234, 2015.

https://www.doi.org/10.1002/pbc.25268

17. C. Metayer, E. Petridou, J. M .Aranguré, E. Roman, J. Schüz et al., "Parental Tobacco Smoking and Acute Myeloid Leukemia: The Childhood Leukemia International Consortium", Am. J. Epidemiol, vol. 184, no. 4, pp. 261-273, 2016.

https://www.doi.org/10.1093/aje/kww018

18. L. Nelson, J. Valle, G. King, P. K. Mills, M. J. Richardson et al., "Estimating the Proportion of Childhood Cancer Cases and Costs Attributable to the Environment in California”, Am. J. Public Health, vol. 107, no. 5, pp. 756-762, 2017. https://www.doi.org/10.2105/AJPH.2017.303690

19. V. L. Boothe, T. K. Boehmer, A. M. Wendel, F. Y. Yip "Residential traffic exposure and childhood leukemia: a systematic review and meta-analysis", Am. J. Prev. Med., vol. 46, no. 4, pp. 413-422, 2014. https://www.doi.org/10.1016/j.amepre.2013.11.004

20. C. Metayer, G. Dahl, J. Wiemels, M. Miller, "Childhood Leukemia: A Preventable Disease", Pediatrics, vol. 138 (Suppl. 1), S45-S55, 2016. https://www.doi.org/10.1542/peds.2015-4268H
21. M. Greaves, "A causal mechanism for childhood acute lymphoblastic leukaemia”, Nat. Rev. Cancer, vol. 18, no. 8, pp. 471-484, 2018.

https://www.doi.org/10.1038/s41568-018-0015-6

22. T. Sorahan, R. J. Lancashire, "Parental cigarette smoking and childhood risks of hepatoblastoma: OSCC data", Br. J. Cancer, vol. 90, no. 5, pp. 1016-1018, 2004. https://www.doi.org/10.1038/sj.bjc.6601651

23. С. К. Пинаев, А. Я. Чижов, “Риск развития эмбриональных опухолей у детей в зависимости от радиации Солнца и дыма лесных пожаров", Радиация и риск, т.29, по.1, стр. 68-78, 2020. (S. K. Pinaev, A. Ya. Chizhov, "Impact of solar activity and the wildfire smoke on the risk of embryonal tumors in young children", Radiation and Risk, vol. 29, no. 1, pp.68-78, 2020)

https://doi.org/10.21870/0131-3878-2020-29-1-6878

24. С. К. Пинаев, А. Я. Чижов, “Системный анализ влияния солнечной радиации и дыма лесных пожаров на риск развития злокачественных новообразований у детей”, Успехи молекулярной онкологии, т. 5, nо. 4, Приложение, стр. 9, 2018 (S. K. Pinaev, A. Ya. Chizhov, "System analysis of the effect of solar radiation and forest fire smoke on the risk of developing malignant neoplasms in children", Adv. Mol. Oncol., App., pp. 9, 2018)

Retrieved from:

http://mol-oncol.com/project/moloncol.com/tezis all.pdf

25. R. Bono, V. Bellisario, R. Tassinari, G. Squillacioti, T. Manetta, M. Bugiani, E. Migliore, P. Piccioni, "Bisphenol A, Tobacco Smoke, and Age as Predictors of Oxidative Stress in Children and Adolescents", Int J. Environ. Res. Public Health, vol. 16, no. 11, 2019. https://www.doi.org/10.3390/ijerph16112025

26. G. Colombo, M. Clerici, D. Giustarini, N. M. Portinaro, G. Aldini et al., "Pathophysiology of tobacco smoke exposure: recent insights from comparative and redox proteomics", Mass. Spectrom. Rev., vol. 33, no. 3, pp. 183-218, 2014. https://pubmed.ncbi.nlm.nih.gov/24272816/ https://www.doi.org/10.1002/mas.21392

27. R. Rabha, S. Ghosh, P. K. Padhy, "Indoor air pollution in rural north-east India: Elemental compositions, changes in haematological indices, oxidative stress and health risks", Ecotoxicol. Environ. Saf., vol. 165, pp. 393-403, 2018. https://www.doi.org/10.1016/i.ecoenv.2018.09.014

28. S. Roychoudhury, N. K. Mondal, S. Mukherjee, A. Dutta, S. Siddique, M. R. Ray, "Activation of protein kinase $\mathrm{B}$ (PKB/Akt) and risk of lung cancer among rural women in India who cook with biomass fuel", Toxicol. Appl. Pharmacol., vol. 259, no. 1, pp. 45-53, 2012.

https://www.doi.org/10.1016/j.taap.2011.12.002

29. S. Ghodbane, A. Lahbib, M. Sakly, H. Abdelmelek, "Bioeffects of static magnetic fields: oxidative stress, genotoxic effects, and cancer studies", Biomed. Res. Int., vol. 2013, Article ID 602987, 2013. https://www.doi.org/10.1155/2013/602987

30. C. Consales, C. Cirotti, G. Filomeni, M. Panatta, A. Butera et al., "Fifty-Hertz Magnetic Field Affects the Epigenetic Modulation of the miR-34b/c in Neuronal Cells", Mol. Neurobiol., vol. 55, no. 7 , pp. 5698-5714, 2018. https://www.doi.org/10.1007/s12035-017-0791-0

31. Е. В. Проскурнина, Ю. А. Владимиров, "Свободные радикалы как участники регуляторных и патологических процессов", Фундаментальные науки - медицине. Биофизические медицинские технологии, Под 
S. K. Pinaev, Environmentally related oxidative stress (EROS)..., RAD Conf. Proc., vol. 4, 2020, 85-89

редакцией А. И. Григорьева и Ю. А. Владимирова, Макс Пресс, Москва, стр. $38-71, \quad 2015 \quad$ (E.V. Proskurnina, Yu. A. Vladimirov, "Free radicals as participants in regulatory and pathological processes", Fundamental sciences - medicine. Biophysical Medical Technologies, Edited by A.I. Grigoriev and Yu.A. Vladimirov, Max Press, Moscow, pp. 38-71, 2015.) Retrieved from:

http://fbm.msu.ru/education/lectures/biophys/pdf/ Проскурнина\%20Т.1\%2038-71.pdf 32. В. В. Давыдов, А. И. Божков, “Карбонильный Журнал НАМН Украӥни, том 20, но. 1, стр. 25-34, 2014 (V. V. Davydov, A. I. Bozhkov, "Carbonyl stress as a nonspecific factor of pathogenesis", Journal of the National Academy of Medical Sciences of Ukraine, vol. 20, no. 1, pp. 25-34, 2014).

Retrieved from:

https://iozdp.org.ua/files/davydov namn 2014.pdf

33. C. N. S. Breda, G. G. Davanzo, P. J. Basso, N. O. Saraiva Câmara, P. M. M. Moraes-Vieira, "Mitochondria as central hub of the immune system", Redox Biol., vol. 26, 101255, 2019. https://www.doi.org/10.1016/j.redox.2019.101255

34. A. V. Kudryavtseva, G. S. Krasnov, A. A. Dmitriev, B. Y. Alekseev, O. L. Kardymon et al., "Mitochondrial dysfunction and oxidative stress in aging and cancer", Oncotarget, vol. 7, no. 29, 44879-44905, 2016.

https://www.doi.org/10.18632/oncotarget.9821

35. М. Г. Завьялова, В. Г. Згода, Е. Н. Николаев, "Определение роли фосфорилирования белков в развитии заболеваний”, Биомедицинская химия, вол. 63, но. 2, стр. 101-114, 2017 (M. G. Zavyalova V. G. Zgoda, E. N. Nikolaev, "Determination of the role of protein phosphorylation in the development of diseases", Biomedical Chemistry, vol. 63, no. 2, pp. 101-114, 2017).

Retrieved from:

http://pbmc.ibmc.msk.ru/ru/article-ru/PBMC-

2017-63-2-101/

https://www.doi.org/10.1134/S1990750817030118

36. J. Yoon, J. R. Terman, "MICAL redox enzymes and actin remodeling: New links to classical tumorigenic and cancer pathways", Mol. Cell. Oncol., vol. 5, no. 1, e1384881, 2017.

https://www.doi.org/10.1080/23723556.2017.13848 $\underline{81}$

37. А. Я. Чижов, С. К. Пинаев, “Экологически обусловленный оксидативный стресс как фактор онкогенеза", Технологии живых систем, но. 1., стр. 47-53, 2012.
(A.Ya. Chizhov, S.K. Pinaev, S. Z. Savin, "Environmentally-related oxidative stress as a carcinogenesis factor", Technologies of living systems, no. 1., pp. 47-53, 2012).

Retrieved from:

https://www.elibrary.ru/item.asp?id=17741394

38. Н. К. Зенков, А. В. Чечушков, П. М. Кожин, Г. Г. Мартинович, Н. В. Кандалинцева, Е. Б. Меньщикова， "Аутофагия как механизм защиты при окислительном стрессе”, “Бюллетень сибирской медицины”, том 18, но. 2, $\begin{array}{llll}\text { cтp. } & 195-214, & 2019 & \text { (N. K. Zenkov, }\end{array}$ A. V. Chechushkov, P. M. Kozhin, G. G. Martinovich, N. V. Kandalintseva, $\quad$ E. B. Menshchikova, "Autophagy as a defense mechanism under oxidative stress", "Bulletin of Siberian medicine ", vol. 18, no. 2, pp. 195-214, 2019)

Retrieved from:

https://www.elibrary.ru/download/elibrary 391860 73 29982430.pdf

39. Q. Qian, W.Chen, Y.Cao, Q.Cao, Y. Cui et al., "Targeting Reactive Oxygen Species in Cancer via Chinese Herbal Medicine", Oxid. Med. Cel.l Longev., vol. 2019:9240426, 2019. https://www.doi.org/10.1155/2019/9240426

40. D. R. Senger, D. Li, S. C. Jaminet, S. Cao, "Activation of the Nrf2 Cell Defense Pathway by Ancient Foods: Disease Prevention by Important Molecules and Microbes Lost from the Modern Western Diet”, PLoS One, vol. 11, no. 2:e0148042, 2016.

https://www.doi.org/10.1371/journal.pone.0148042

41. G. Filomeni, D. De Zio, F. Cecconi, "Oxidative stress and autophagy: the clash between damage and metabolic needs", Cell Death. Differ., vol. 22, no. 3, pp. 377-388, 2015.

42. "Иммунореабилитация при инфекционновоспалительных и соматических заболеваниях с использованием Трансфер Факторов. Методическое письмо”, Министерство здравоохранения и социального развития Российской Федерации, 34, 2004. ("Immunorehabilitation in infectious-inflammatory and somatic diseases using Transfer Factors. Methodological letter", Ministry of Health and Social Development of the Russian Federation, 34, 2004).

43. Prescriber's Digital Reference, “4Life Transfer Factor Tri-Factor Formula".

Retrieved from:

https://pdr.net/full-prescribing-information/4lifetransfer-factor-tri-factor?druglabelid $=159$ 